\title{
Association of the -344T/C Aldosterone Synthase Gene Variant with Essential Hypertension
}

\author{
Z. HLUBOCKÁ ${ }^{1}$, M. JÁCHYMOVÁ ${ }^{2}$, S. HELLER ${ }^{1}$, V. UMNEROVÁ ${ }^{1}$, V. DANZIG $^{1}$, V. $^{\prime}$ \\ LÁNSKÁ $^{3}$, K. HORKÝ ${ }^{1}$, A. LINHART ${ }^{1}$ \\ ${ }^{1}$ Second Medical Department - Clinical Department of Cardiology and Angiology and ${ }^{2}$ Department \\ of Biochemistry and Laboratory Methods, First Faculty of Medicine and General University \\ Hospital, Charles University, Prague, ${ }^{3}$ Institute for Clinical and Experimental Medicine, Prague, \\ Czech Republic
}

Received November 19, 2007

Accepted October 24, 2008

On-line December 17, 2008

\section{Summary}

The aldosterone synthase gene (CYP11B2) is an important candidate gene region in essential hypertension. We therefore studied the association of -344 T/C polymorphism of the CYP11B2 gene with the presence and severity of hypertension in a case-control study. We studied 369 individuals, of whom 213 were hypertensive patients (139 controlled hypertensive, 74 resistant hypertensive) and 156 were healthy normotensive subjects. The $-344 \mathrm{~T} / \mathrm{C}$ polymorphism of the CYP11B2 gene was determined using polymerase chain reaction - restriction fragment length polymorphism analysis. The distribution of genotypes in normotensive controls and hypertensive subjects were: $\Pi 25.6$ vs. $31.9 \%$, TC 51.9 vs. $57.3 \%$ and CC 22.4 vs. $10.8 \%$. The $-344 \mathrm{~T} / \mathrm{C}$ variant was associated with hypertension. Subjects carrying the $-344 \mathrm{~T}$ allele had a greater risk of hypertension compared to those having $C$ allele $\left(X^{2}=5.89\right.$, $p<0.05)$. The frequency of CC genotype was significantly lower in hypertensive patients than in normotensive controls $\left(X^{2}=9.44\right.$, $p<0.01$ ). A stepwise logistic regression analysis confirmed these findings. We did not find an association of $-344 \mathrm{~T} / \mathrm{C}$ variant with the resistance of hypertensive patients to combination therapy, but we observed an association of $-344 \mathrm{~T} / \mathrm{C}$ polymorphism of aldosterone synthase gene with increased risk of hypertension. These results support a potential role of -344T/C CYP11B2 gene polymorphism in genetic predisposition to develop hypertension.

\section{Key words}

Aldosterone synthase - Hypertension - Polymorphism • Aldosterone

\section{Corresponding author}

Z. Hlubocká, Second Medical Department - Clinical Department of Cardiology and Angiology, First Faculty of Medicine, Charles University, U nemocnice 2, 12808 Prague 2, Czech Republic. Fax: +4202 2491 2154. E-mail: hlubockaz@seznam.cz

\section{Introduction}

The renin-angiotensin-aldosterone system is an important regulator of blood pressure and molecular variants in genes that encode components of this system have been associated with several cardiovascular diseases, such as essential hypertension, myocardial infarction and hypertrophic cardiomyopathy.

Among them the CYP11B2 gene encodes a key enzyme of the aldosterone biosynthesis - aldosterone synthase. Aldosterone is an independent risk factor for cardiovascular diseases and development of cardiac hypertrophy and fibrosis. Aldosterone synthase includes the steroid 11ß-hydroxylase, 18-hydroxylase and 18-oxidase activities that are required for the final steps of aldosterone biosynthesis. A related enzyme, $11 \beta$-hydroxylase (CYP11B1), is responsible mainly for cortisol biosynthesis, although changes in its activity can also influence biosynthesis of steroid metabolites with mineralocorticoid actions. The two relevant genes (CYP11B2, CYP11B1) are located in a close proximity on chromosome 8q22. It is now apparent from investigation of rare monogenic forms of hypertension 
and animal models that changes in the expression and activity of these enzymes can affect sodium homeostasis and thereby blood pressure through defects in mineralocorticoid metabolism. CYP11B2 is thus an obvious gene to test for association with hypertension (Brand et al. 1998, Freel and Connell 2004).

To date, three common genetic variants of the aldosterone synthase gene (CYP11B2) have been identified as possible determinants of high blood pressure in patients with essential hypertension (White and Slutsker 1995, Mulatero et al. 2000, Zhu et al. 2003). One is a single nucleotide polymorphism in the 5 ' promoter region at $-344 \mathrm{~T} / \mathrm{C}$ that alters a putative recognition site for steroidogenic transcription factor-1 (SF-1). The other polymorphism involves intron 2 of CYP11B2, which is partly replaced by the corresponding intron of CYP11B1 gene. These two polymorphisms are in close linkage disequilibrium. The third polymorphism is a point mutation $\mathrm{K} 173 \mathrm{R}$ in exon 3.

Several studies of association between $-344 \mathrm{~T} / \mathrm{C}$ polymorphism and essential hypertension have been published, with controversial results. Whereas some have found that the T-allele is more common in hypertension and subjects with increased urinary aldosterone excretion rate (Brand et al.1998, Davies et al. 1999, Kumar et al. 2003, Casiglia et al. 2005), others have demonstrated no association of either allele with hypertension or other cardiovascular disease (Brand et al. 1999, Schunkert et al. 1999, Kato et al. 2000, Tsujita et al. 2001). It was also suggested that the $\mathrm{C}$ allele may be associated with genetic predisposition to hypertension in Hani and Yi minorities in China (Tang et al. 2006). Several factors such as ethnicity, gender and age could be involved in the phenotypic expression of this polymorphism.

Some studies evaluated the impact of $-344 \mathrm{~T} / \mathrm{C}$ polymorphism of the CYP11B2 on the severity of hypertension and blood pressure-lowering response to antihypertensive drugs (Kurland et al. 2002, Tiago et al. 2003). Because the severity of hypertension determines cardiovascular risk and aldosterone is an important therapeutic target in hypertension, genotyping for the $-344 \mathrm{~T} / \mathrm{C}$ polymorphism of the CYP11B2 gene may have prognostic as well as therapeutic potential in hypertensive patients.

The present study was designed to investigate the association of $-344 \mathrm{~T} / \mathrm{C}$ polymorphism of the CYP11B2 gene with genetic predisposition to essential hypertension. Furthermore, we examined whether this polymorphism is associated with resistance of hypertensive patient to combined antihypertensive therapy.

\section{Materials and Methods}

\section{Study groups and clinical assessment}

We examined a total of 369 individuals, of whom 213 were patients with essential hypertension and 156 were healthy normotensive subjects. All subjects were unrelated Caucasians from the Bohemia region of the Czech Republic. Hypertensive patients were sequentially enrolled from the outpatient clinic of Second Medical Department - Clinical Department of Cardiology and Angiology, First Faculty of Medicine and General University Hospital, Prague. Hypertension was defined according to the following criteria: (i) systolic blood pressure $(\mathrm{BP}) \geq 140 \mathrm{~mm} \mathrm{Hg}$ or diastolic $\mathrm{BP} \geq 90 \mathrm{~mm} \mathrm{Hg}$, or both, measured on two consecutive visits for untreated subjects; (ii) patients receiving long-term antihypertensive treatment; (iii) no clinical or biochemical evidence of secondary hypertension. Normotensive subjects were selected from outpatients who participated in voluntary health checks and hospital staff undergoing annual medical examinations. The subjects were considered to be normotensive when their systolic blood pressure was lower than $140 \mathrm{~mm} \mathrm{Hg}$ and diastolic blood pressure below $90 \mathrm{~mm} \mathrm{Hg}$. All subjects had normal renal function and no history of diabetes, heart disease or other serious illness. Informed consent was obtained from each subject and the study was approved by the local ethic committee.

To phenotype hypertensive subjects further they were subdivided according to the severity of hypertension into two groups: patients well-controlled after adjustment of lifestyle and medication [controlled hypertension group $(\mathrm{CH}), \mathrm{n}=139$ ] and subjects resistant to combined antihypertensive therapy [resistant hypertension group (RH), n=74]. Hypertensive patients were considered resistant to therapy if they had systolic BP $\geq 140 \mathrm{~mm} \mathrm{Hg}$ and/or diastolic BP $\geq 90 \mathrm{~mm} \mathrm{Hg}$ when on a triple antihypertensive therapy including diuretics.

\section{Genotyping}

Genomic DNA was isolated form peripheral leukocytes according to the standard method (Miller et al. 1988). The -344T/C polymorphism of the CYP11B2 gene was determined by the analysis of restriction fragment length polymorphism (RFLP) (Komiya et al. 2000) (Fig. 1). The DNA fragment containing $-344 \mathrm{~T} / \mathrm{C}$ of the 
CYP11B2 gene was amplified by polymerase chain reaction (PCR). The PCR was performed using Taq polymerase Boehring Ingelheim and oligonucleotide primers CTCACCCAGGAACCTGCTCTGGAAACATA and CAGGAGGGATGAGCAGGCAGAGCACAG using hot start and touchdown PCR to increase specificity of the reaction. PCR was subjected to $94{ }^{\circ} \mathrm{C}$ for $30 \mathrm{~s}$ and from $62{ }^{\circ} \mathrm{C}$ to $58{ }^{\circ} \mathrm{C}$, two cycles $1{ }^{\circ} \mathrm{C}$ lower temperature annealing, $72{ }^{\circ} \mathrm{C}$ for $30 \mathrm{~s}$ for amplification to the total amount of 35 cycles followed by final extension for $5 \mathrm{~min}$, producing a fragment of $639 \mathrm{bp}$. This fragment was subsequently cleaved by HaeIII, creating fragments for allele T 402, 138, 51 and $48 \mathrm{bp}$, and for allele C 334, 138, 68, 51 and $48 \mathrm{bp}$, which where subjected to electrophoresis on a metaphoragarose gel and visualized with ethidium bromide. The samples from hypertensive patients and healthy controls were also analyzed by DNA sequence analysis to confirm results of the PCR-RFLP method.

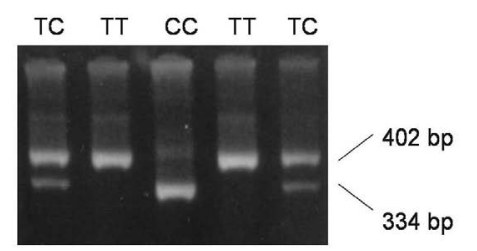

Homozygotes for $-344 T$ allele are in lanes TT, homozygotes for $-344 \mathrm{C}$ allele are in lane $\mathrm{CC}$, and heterozygotes are in lanes TC.

Fig. 1. Genotype determination of the $-344 \mathrm{~T} / \mathrm{C}$ CYP11B2 gene polymorphism.
Statistical analysis

Statistical analysis was performed using SYSTAT 10 statistical software (SPSS Inc., 2000). Data are given as means \pm S.D. Differences in clinical variables between case and control groups were tested using one-way analysis of variance (ANOVA). The Hardy-Weinberg equilibrium and allele frequency and genotype distributions were tested by $\chi^{2}$ statistic (Falconer and Mackay 1996). A stepwise logistic regression analysis was conducted to adjust for covariates including age, gender, body mass index (BMI), blood glucose, serum triglycerides, total cholesterol, LDLcholesterol and HDL-cholesterol plasma levels. Association of phenotypic parameters (BP levels, age, sex, BMI) with genotype was assessed by one-way ANOVA for continuous variables and $\chi^{2}$ test for discrete variables. All statistical tests were two-tailed and values of $\mathrm{p}<0.05$ were considered to represent statistically significant differences.

\section{Results}

\section{Clinical characteristics of the study groups}

The overall characteristics of the study subjects genotyped for the $-344 \mathrm{~T} / \mathrm{C}$ CYP11B2 gene polymorphism are listed in Table 1. Systolic and diastolic blood pressure was markedly higher in patients with essential hypertension ( $\mathrm{H}$ group) than in normotensive

Table 1. Clinical characteristics of the study groups.

\begin{tabular}{|c|c|c|c|c|}
\hline & \multirow[t]{2}{*}{$\begin{array}{l}\text { Normotensive } \\
\text { subjects }\end{array}$} & \multicolumn{2}{|c|}{$\begin{array}{l}\text { Hypertensive subjects } \\
\qquad \mathbf{n}=\mathbf{2 1 3}\end{array}$} & \multirow{2}{*}{ p (ANOVA) } \\
\hline & & $\begin{array}{c}\text { Controlled } \\
\text { hypertensive }\end{array}$ & $\begin{array}{c}\text { Resistant } \\
\text { hypertensive }\end{array}$ & \\
\hline$n$ & 156 & 139 & 74 & \\
\hline Age (years) & $51.3 \pm 9.7$ & $56.6 \pm 10.5^{*}$ & $61.4 \pm 8.74 *$ & $\mathrm{p}<0.001$ \\
\hline Systolic BP (mmHg) & $122 \pm 10.4$ & $144 \pm 16.9 *$ & $152 \pm 16.1^{*}$ & $\mathrm{p}<0.001$ \\
\hline Diastolic BP (mmHg) & $79.6 \pm 6.45$ & $90.1 \pm 8.61 *$ & $95.3 \pm 8.27 *$ & $\mathrm{p}<0.001$ \\
\hline$B M I\left(k g / m^{2}\right)$ & $26.1 \pm 3.41$ & $28.5 \pm 4.37 *$ & $29.8 \pm 3.79 *$ & $\mathrm{p}<0.001$ \\
\hline Fasting glucose ( $\mathrm{mmol} / \mathrm{l})$ & $5.29 \pm 0.73$ & $5.98 \pm 1.74^{*}$ & $6.36 \pm 2.27 *$ & $\mathrm{p}<0.001$ \\
\hline Serum-total cholesterol ( $\mathrm{mmol} / \mathrm{l})$ & $5.43 \pm 0.94$ & $5.45 \pm 1.16$ & $5.19 \pm 0.94$ & n.s. \\
\hline Triglycerides $(\mathrm{mmol} / \mathrm{l})$ & $1.43 \pm 0.94$ & $1.87 \pm 1.22 *$ & $1.87 \pm 0.84 *$ & $\mathrm{p}<0.01$ \\
\hline HDL-cholesterol (mmol/l) & $1.40 \pm 0.30$ & $1.29 \pm 0.31 *$ & $1.23 \pm 0.30 *$ & $\mathrm{p}<0.01$ \\
\hline LDL-cholesterol (mmol/l) & $3.39 \pm 0.77$ & $3.36 \pm 0.91$ & $3.11 \pm 0.81$ & n.s. \\
\hline
\end{tabular}

Data are expressed as means \pm S.D., $* p<0.05$ for controlled hypertensives, resistant hypertensives versus normotensives by one-way ANOVA. BP = blood pressure, BMI = body mass index, HDL = high density lipoprotein, $L D L=$ low density lipoprotein, n.s. = not significant, ANOVA = analysis of variance. 
group ( $\mathrm{N}$ group). In addition, as expected, body mass index (BMI) and fasting blood glucose were significantly higher in $\mathrm{H}$ group than in $\mathrm{N}$ group. No significant differences were detected between groups with respect to height, total cholesterol and LDL-cholesterol levels. Plasma levels of LDL-cholesterol revealed a nonsignificant tendency to lower concentrations in hypertensive than in normotensive subjects. This finding corresponds to a significant number of hypertensive patients treated by statin therapy. However, serum triglycerides were higher and serum HDL cholesterol was lower in hypertensive than in normotensive group.

Table 2. Association analysis of $-344 T / C$ CYP11B2 gene polymorphism in hypertensives versus normotensives.

Genotype frequencies (n, \%)

\begin{tabular}{ccccc}
\hline Group $(n)$ & $\mathrm{TT}$ & $\mathrm{TC}$ & $\mathrm{CC}$ & $\mathrm{p}$ \\
& $(\mathrm{n}=108)$ & $(\mathrm{n}=203)$ & $(\mathrm{n}=58)$ & \\
Normotensive & 40 & 81 & 35 & \\
subjects & $(37.0 \%)$ & $(39.9 \%)$ & $(60.3 \%)$ & $\mathrm{p}<0.01$ \\
Hypertensive & 68 & 122 & 23 & $\chi^{2}=9.44$ \\
patients & $(63.0 \%)$ & $(60.1 \%)$ & $(39.7 \%)$ & \\
\hline
\end{tabular}

Allele frequencies (n, \%)

\begin{tabular}{cccc}
\hline Group $(n)$ & $\mathrm{T}(\mathrm{n}=419)$ & $\mathrm{C}(\mathrm{n}=319)$ & $\mathrm{p}$ \\
$\begin{array}{c}\text { Normotensive } \\
\text { subjects }\end{array}$ & $161(38.4 \%)$ & $151(47.3 \%)$ & \\
$\begin{array}{c}\text { Hypertensive } \\
\text { patients }\end{array}$ & $258(61.6 \%)$ & $168(52.7 \%)$ & $\mathrm{p}<0.05$ \\
$\chi^{2}=5.89$ \\
\hline
\end{tabular}

Genotypes and alleles indicated as percentage and number. Statistical analysis by $\chi^{2}$ test.

Association between aldosterone synthase variants and essential hypertension

Table 2 shows the distribution of genotypes and alleles for the $-344 \mathrm{~T} / \mathrm{C}$ CYP11B2 gene polymorphism in hypertensive subjects and normotensive controls.

Frequencies of genotypes were in accordance with the Hardy-Weinberg equilibrium in normotensive group. On the contrary the observed genotype frequencies deviated from that expected from the Hardy-Weinberg equilibrium in hypertensive group $(\mathrm{p}<0.01)$.

We found a significant association of the $-344 \mathrm{~T} / \mathrm{C}$ CYP11B2 gene polymorphism with essential hypertension. Subjects carrying the $-344 \mathrm{~T}$ allele had significantly greater risk of essential hypertension compared with those carrying $\mathrm{C}$ allele. The $\mathrm{CC}$ genotype was twice as prevalent in the normotensive as in hypertensive patients (Table 2). In the logistic regression analysis we observed significant association of $-344 \mathrm{~T} / \mathrm{C}$ aldosterone synthase gene polymorphism and hypertension ( $\mathrm{TC}$ vs. $\mathrm{CC}$ : odds ratio $=3.4,95 \%$ confidence interval 1.3-9.1; TT vs. CC: odds ratio $=5.4$, $95 \%$ confidence interval 1.8-16) after adjustment for the covariates of age, gender, BMI, blood glucose and blood lipid levels. We failed to observe any significant difference in the genotype distribution or allele frequencies between hypertensive subjects wellcontrolled with antihypertensive therapy ( $\mathrm{CH}$ group) and resistant hypertensive group (RH group) either by $\chi^{2}$ statistics or logistic regression analysis.

The associations between phenotypic characteristics and aldosterone synthase genotype were analyzed for the normotensive and hypertensive groups separately, as well as in the combined group of normotensive and hypertensive subjects. One-way ANOVA analysis did not show a significant influence of genotype on systolic or diastolic BP. Finally, no significant differences in terms of gender distribution, age, body mass index, glucose and cholesterol concentrations were detected among the genotypes.

\section{Discussion}

In the present study, we investigated the association between the $-344 \mathrm{~T} / \mathrm{C}$ polymorphism in the promoter region of the human CYP11B2 gene and essential hypertension. Our results showed that the genotype and allele distribution differed significantly between hypertensive and normotensive groups. The $-344 \mathrm{~T}$ allele and TT genotype were associated with genetic predisposition to develop hypertension.

A number of studies have suggested the implication of CYP11B2 gene polymorphism in the pathogenesis of cardiovascular disease. However, previous data on the association between the $-344 \mathrm{~T} / \mathrm{C}$ polymorphism and hypertension or with hypertensive intermediate phenotypes such as plasma renin activity and plasma aldosterone concentration gave controversial results. Our findings are in agreement with several studies previously conducted in Caucasians, also showing association of $-344 \mathrm{~T}$ allele with hypertension or blood pressure levels (Brand et al. 1998, Davies et al. 1999, Casiglia et al. 2005). At variance with these 
reports, other studies conducted in Caucasian populations did not find any association (Brand et al. 1999, Schunkert et al. 1999). Kumar et al. (2003) reported that the $C$ allele was associated with hypertension in Caucasian women. No association between the $\mathrm{T}$ allele and hypertension has also been reported in several Japanese studies (Kato et al. 2000, Tsujita et al. 2001, Isaji et al. 2005) and in one of them hypertension was associated with the $\mathrm{C}$ allele (Tamaki et al. 1999). Similar inconsistencies have characterized the reports linking this polymorphism to plasma or urinary aldosterone levels (Brand et al. 1998, Davies et al. 1999, Connell et al. 2004). Several reasons could account for these inconsistent results. First, the associations could be influenced by the different genetic background and environmental factors in geographically separated populations. Furthermore, the differences in study design and selection criteria, such as different age (Casiglia et al. 2005), gender (Tsujita et al. 2001) or different proportions of individuals with low renin hypertension (Zhu et al. 2003) might be responsible for these discrepancies. In a recent meta-analysis Sookoian et al. (2007) showed that subjects homozygous for the $-344 \mathrm{~T}$ allele of the CYP11B2 gene have, at least, a $17 \%$ greater risk of essential hypertension than their $-344 \mathrm{CC}$ counterparts.

The exact mechanism, whereby the $-344 \mathrm{~T} / \mathrm{C}$ polymorphism of CYP11B2 gene variant may lead to higher blood pressure remains unknown. Recent studies suggest that the $-344 \mathrm{~T} / \mathrm{C}$ variant by itself does not directly influence promoter activity despite its location within a SF-1 binding site. Rather, binding of SF-1 to this site downregulates activity of CYP11B2 promoter by making SF-1 less available to functionally affect other CYP11B2 promoter sites, which could alter expression of the gene (Clyne et al. 1997). Moreover, in vitro studies showed that $\mathrm{C}$ allele binds SF-1 fourfold more strongly than it does the T allele (White and Slutsker 1995). This may allow a change in CYP11B2 promoter activity and expression (Hautanen et al. 1998, Matsubara et al. 2004).

In a previous study conducted in normotensive healthy men we observed higher plasma renin activity (PRA) in TT homozygotes and higher values of left ventricular mass index in individuals with TT genotype and high PRA (Heller et al. 2004). In agreement with these findings a recent meta-analysis also revealed higher PRA and no difference in plasma aldosterone levels in homozygous TT individuals (Sookoian et al. 2007). We may speculate that higher PRA reported in TT homozygous individuals may be adaptive to a lack of adequate response of the CYP11B2 promoter bearing the $\mathrm{T}$ allele to the angiotensin II-mediated stimulus. Therefore the elevated plasma angiotensin II may make TT homozygous subjects more prone to hypertension (Heller et al. 2004, Sookoian et al. 2007, Staessen et al. 2007).

The evaluation of hypertensive patients selected according to the severity of hypertension may increase the genetic component of hypertension and thus improve the likelihood of detecting any existing genetic association with hypertension. Studies conducted in hypertensive patients that examined the relationship between candidate gene polymorphisms and the severity of hypertension or presence of resistant hypertension has provided contradictory data. While some studies have reported an association of $-344 \mathrm{~T} / \mathrm{C}$ polymorphism of aldosterone synthase gene, I/D polymorphism of ACE gene, A1166C polymorphism of AT1-receptor gene and G894T polymorphism of the endothelial nitric oxide synthase gene with severity of BP changes, resistant hypertension, malignant hypertension or hypertensive crisis, others did not confirm these results (Brand et al. 1998, O’Donnell et al. 1998, Stefansson et al. 2000, Jáchymová et al. 2001, Sunder-Plassmann et al. 2002, Tiago et al. 2003). In the present study we evaluated the impact of $-344 \mathrm{~T} / \mathrm{C}$ polymorphism of CYP11B2 gene on the severity of hypertension by comparing hypertensive subjects well-controlled by conventional therapy and patients with resistant hypertension. We did not observe association between CYP11B2 genotype groups and presence of resistant hypertension. We found high frequency of resistant hypertension in our study. Although the prevalence of resistant hypertension is unknown, the data from recent hypertension outcome trials (VALUE, ALLHAT, CONVINCE) indicate that it is greater than previously thought (Cushman et al. 2002, Black et al. 2003, Julius et al. 2003). On the other hand, patients enrolled in hypertension clinic of our hospital are generally those with moderate to severe or uncontrolled hypertension. Thus, we think that the number of patients with resistant hypertension in our study overestimates the occurrence of resistant hypertension in hypertensive population.

Several studies investigating the role of $-344 \mathrm{~T} / \mathrm{C}$ aldosterone synthase gene polymorphism on blood pressure described an association of BP levels with -344T allele (Brand et al. 1998, Brand et al. 1999, Matsubara et al. 2001, Tiago et al. 2003, Barbato et al. 2004). However, in the study of Brand et al. (1998) the 
relationship was significant only in the subgroup of severely hypertensive patients of African ethnicity with BMI greater than $27 \mathrm{~kg} / \mathrm{m}^{2}$. In contrast, other crosssectional and case-control studies as well as the metaanalysis by Sookoian et al. (2007) did not confirm the role of aldosterone synthase gene polymorphism in determining BP levels (Brand et al. 1998, Brand et al. 1999, Kupari et al. 1998, Tsujita et al. 2001, Tiago et al. 2003). In our study, we did not demonstrate the influence of genotype on systolic and diastolic BP levels. However, since we were unable to discontinue therapy in our outpatients, and the assessment of pretreatment blood pressure levels was not available, such analysis is inevitably biased. The genetic effects on BP levels in our study population may have been modified by the antihypertensive medication. Finally, we did not observe any significant differences among the genotypes in terms of gender distribution, age, BMI, glucose and cholesterol concentrations.

In summary, we have observed an association of $-344 \mathrm{~T} / \mathrm{C}$ polymorphism of aldosterone synthase gene with hypertension in case-control study in Caucasian subjects from Czech Republic. These results support a potential role of $-344 \mathrm{~T} / \mathrm{C}$ CYP11B2 gene polymorphism in mechanisms affecting blood pressure regulation. Further studies of this locus should be performed in large-scale populations to confirm our results and to define the underlying physiological and clinical implications of observed association.

\section{Conflict of Interest}

There is no conflict of interest.

\section{Acknowledgements}

Study supported by the research project from the Ministry of Health of the Czech Republic (MZO VFN2005).

\section{References}

BARBATO A, RUSSO P, SIANI A, FOLKERD EJ, MILLER MA, VENEZIA A, GRIMALDI C, STRAZZULLO P, CAPPUCCIO FP: Aldosterone synthase gene (CYP11B2) C-344T polymorphism, plasma aldosterone, renin activity and blood pressure in a multi-ethnic population. J Hypertens 22: 1895-1901, 2004.

BLACK HR, ELLIOTT WJ, GRANDITS G, GRAMBSCH P, LUCENTE T, WHITE WB, NEATON JD, GRIMM RH JR, HANSSON L, LACOURCIERE Y, MULLER J, SLEIGHT P, WEBER MA, WILLIAMS G, WITTES J, ZANCHETTI A, ANDERS RJ; CONVINCE RESEARCH GROUP: Principal results of the controlled onset verapamil investigation of cardiovascular end points (CONVINCE) trial. JAMA 289: 2073-2082, 2003.

BRAND E, CHATELAIN N, MULATERO P, FERY I, CURNOW K, JEUNEMAITRE X, CORVOL P, PASCOE L, SOUBRIER F: Structural analysis and evaluation of the aldosterone synthase gene in hypertension. Hypertension 32: 198-204, 1998.

BRAND E, SCHODE U, RINGEL J, BRITE J, DISTLER A, SHARMA AM: Aldosterone synthase gene (CYP11B2) polymorphism in Caucasians from the Berlin Salt-Sensitive Trial (BeSST). J Hypertens 17: 1563-1567, 1999.

CASIGLIA E, TIKHONOFF V, MAZZA A, RYNKIEWICZ A, LIMON J, CAFFI S, GUGLIELMI F, MARTINI B, BASSO G, WINNICKI M, PESSINA AC, SOMERS VK: C-344T polymorphism of the aldosterone synthase gene and blood pressure in the elderly: a population-based study. J Hypertens 23: 1991-1996, 2005.

CLYNE CD, ZHANG Y, SLUTSKER L, MATHIS JM, WHITE PC, RAINEY WE: Angiotensin II and potassium regulate human CYP11B2 transcription through common cis-elements. Mol Endocrinol 11: 638-649, 1997.

CONNELL JM, FRASER R, MACKENZIE SM, FRIEL EC, INGRAM MC, HOLLOWAY CD, DAVIES E: The impact of polymorphisms in the gene encoding aldosterone synthase (CYP11B2) on steroid synthesis and blood pressure regulation. Moll Cell Endocrinol 217: 243-247, 2004.

CUSHMAN WC, FORD CE, CUTLER JA, MARGOLIS KL, DAVIS BR, GRIMM RH, BLACK HR, HAMILTON BP, HOLLAND J, NWACHUKU C, PAPADEMETRIOU V, PROBSTFIELD J, WRIGHT JT JR, ALDERMAN MH, WEISS RJ, PILLER L, BETTENCOURT J, WALSH SM, ALLHAT COLLABORATIVE RESEARCH GROUP: Success and predictors of blood pressure control in diverse North American settings: the antihypertensive and lipid-lowering treatment to prevent heart attack trial (ALLHAT). J Clin Hypertens $\mathbf{4}$ : 393-404, 2002. 
DAVIES E, HOLLOWAY CD, INGRAM MC, INGLIS GC, FRIEL EC, MORRISON C, ANDERSON NH, FRASER R, CONNELL JM: Aldosterone excretion rate and blood pressure in essential hypertension are related to polymorphic differences in the aldosterone synthase gene CYP11B2. Hypertension 33: 703-707, 1999.

FALCONER DS, MACKAY FC: Introduction to Quantitative Genetics. Longman Group Ltd, London, 1996.

FREEL EM, CONNELL JM: Mechanisms of hypertension: the expanding role of aldosterone. J Am Soc Nephrol 15: 1993-2001, 2004.

HAUTANEN A, LANKIEN L, KAPUCI M, JANNE OA, ADLERCREUTZ H, NIKKILA H, WHITE PC: Associations between aldosterone synthese gene polymorphism and adrenocortical function in males. $J$ Intern Med 244: 11-18, 1998.

HELLER S, LINHART A, JINDRA A, JÁCHYMOVÁ M, HORKÝ K, PELEŠKA J, HLUBOCKÁ Z, UMNEROVÁ V, ASCHERMANN M: Association of $-344 / T / C$ aldosterone synthase polymorphism (CYP11B2) with left ventricular structure and humoral parameters in young normotensive men. Blood Press 13: 158-163, 2004.

ISAJI M, MUNE T, TAKADA N, YAMAMOTO Y, SUWA T, MERITA H, TAKEDA J, WHITE PC: Correlation between left ventricular mass and urinary sodium excretion in specific genotypes of CYP11B2. J Hypertens 23: 1149-1157, 2005.

JÁCHYMOVÁ M, HORKÝ K, BULTAS J, KOŽICH V, JINDRA A, PELEŠKA J, MARTÁSEK P: Association of the Glu298Asp polymorphism in the endothelial nitric oxide synthase gene with essential hypertension resistant to conventional therapy. Biochem Biophys Res Commun 284: 426-430, 2001.

JULIUS S, KJELDSEN SE, BRUNNER H, HANSSON L, PLATT F, EKMAN S, LARAGH JH, MCINNES G, SCHORK AM, SMITH B, WEBER M, ZANCHETTI A; VALUE TRIAL: VALUE trial: long-term blood pressure trends in 13,449 patients with hypertension and high cardiovascular risk. Am J Hypertens 16: 544548, 2003.

KATO N, SUGIYAMA T, MERITA H, KURIHARA H, FURUKAWA T, ISSHIKI T, SATO T, YAMORI Y, YAZAKI Y: Comprehensive analysis of the renin-angiotensin gene polymorphisms with relation to hypertension in the Japanese. J Hypertens 18: 1025-1032, 2004.

KOMIYA I, YAMADA T, TAKARA M, ASAWA T, SHIMABUKURO M, NISHIMORI T, TAKASU N: Lys(173)Arg and $-344 \mathrm{~T} / \mathrm{C}$ variants of CYP11B2 in Japanese patients with low-renin hypertension. Hypertension 35: 699-703, 2000.

KUMAR NN, BENJAFIELD AV, LIN RC, WANG WY, STOWASSER M, MORFIA BJ: Haplotype analysis of aldosterone synthase gene CYP11B2 polymorphism shows association with essential hypertension. J Hypertens 21: 1331-1337, 2003.

KUPARI M, HAUTANENA A, LANKINEN L, KOSKINEN P, VIROLAINEN J, NIKKILA H, WHITE PC: Associations between human aldosterone synthase (CYP11B2) gene polymorphisms and left ventricular size, mass, and function. Circulation 97: 569-575, 1998.

KURLAND L, MELHUS H, KARLSSON J, KAHAN T, MALMQVIST K, LIND L: Aldosterone synthase (CYP11B2) $-344 \mathrm{C} / \mathrm{T}$ polymorphism is related to antihypertensive response: results from the Swedish Irbesartan Left Ventricular Hypertrophy Investigation versus Atenolol (SILVHIA) trial. Am J Hypertens 15: 389-393, 2002.

MATSUBARA M, KIKUYA M, OHKUBO T, METOKI H, OMORI F, FUJIWARA T, SUZUKI M: Aldosterone synthase gene (CYP11B2) C-344T polymorphism, ambulatory blood pressure and nocturnal decline in blood pressure in the general Japanese population: the Ohasama Study. J Hypertens 19: 2179-2184, 2001.

MATSUBARA M, SATO T, NISHIMURA T, SUZUKI M, KIKUYA M, METOKI H, MICHIMATA M, TSUJI I, OGIHARA T, IMAI Y: CYP11B2 polymorphisms and home blood pressure in a population-based cohort in Japanese: the Ohasama Study. Hypertens Res 27: 1-6, 2004.

MILLER SA, DYKES DD, POLESKY HF: A simple salting out procedure for extraction DNA from human nucleated cells. Nucleid Acids Res 16: 1215, 1988.

MULATERO P, SCHIAVONE D, FALLO F, RABBIA F, VEGLIO F: CYP11B2 gene polymorphisms in idiopathic hyperaldosteronism. Hypertension 35: 694-698, 2000. 
O'DONNELL CK, LINDPAINTNER K, LARSON MG, RAO VS, ORDOVAS JM, SCHAEFER EJ, MYERS RH, LEVY D: Evidence for association and genetic linkage of the angiotensin-converting enzyme locus with hypertension and blood pressure in men but not women in the Framingham Heart Study. Circulation 97: 1766$1772,1998$.

SCHUNKERT H, HENGSTENBERG C, HOLME SR, BROECKEL U, LUCHNER A, MUSCHOLL MW, KURZINGER S, DORING A, HENSE HW, RIEGGER GA: Lack of association between a polymorphism of the aldosterone synthase gene and left ventricular structure. Circulation 99: 2255-2260, 1999.

SOOKOIAN S, GIANOTTI TF, GONZALEZ CD, PIROLA CJ: Association of the C-344T aldosterone synthese gene variant with essential hypertension: a meta-analysis. J Hypertens 25: 5-13, 2007.

STAESSEN JA, LI Y, THIJS L: Meta-analysis of blood pressure and the CYP11B2 polymorphism highlights the need for better designed studies. J Hypertens 25: 37-39, 2007.

STEFANSSON B, RICKSTEN A, RYMO L, AURELL M, HERLITZ H: Angiotensin-converting enzyme gene I/D polymorphism in malignant hypertension. Blood Press 9: 104-109, 2000.

SUNDER-PLASSMANNG, KITTLER H, BERLE C, HIRSCHL MM, WOISETSCHAGER CH, DERHASCHNIG U, LAGGNER AN, HORL WH, FODINGER M: Angiotensin concerting enzyme DD genotype is associated with hypertension crisis. Crit Care Med 30: 2236-2241, 2002.

TAMAKI S, IWAI N, TSUJITA Y, KINOSHITA M: Genetic polymorphism of CYP11B2 gene and hypertension in Japanese. Hypertension 33: 266-270, 1999.

TANG W, WU H, ZHOU X, CHEBY B, DONG Y, HE L, YU H, XU L, LU J, LI K, XIAO CH: Association of the C-344T polymorphism of CYP11B2 gene with essential hypertension in Hani and Yi minorities of China. Clin Chim Acta 364: 222-225, 2006.

TIAGO AD, BADENHORST D, NKEH B, CANDY GP, BROOKSBANK R, SARELI P, LIBHABER E, SAMANI NJ, WOODIWISS AJ, NORTON GR: Impact of renin-angiotensin-aldosterone system gene variants on the severity of hypertension in patients with newly diagnosed hypertension. Am J Hypertens 16: 1006-1010, 2003.

TSUJITA Y, IWAI N, KATSUYA T, GIGAMI J, OGIHARA T, TAMAKI S, KINOSHITA M, MANNAMI T, OGATA J, BABA S: Lack of association between genetic polymorphism of CYP11B2 and hypertension in Japanese: the Suita Study. Hypertens Res 24: 105-109, 2001.

WHITE PC, SLUTSKER L: Haplotype analysis of CYP11B2. Endocr Res 21: 437-42, 1995.

ZHU H, SAGNELLA GA, DONG Y, MILLER MA, ONIPINLA A, MAKANDU ND, MACGREGOR GA: Contrasting associations between aldosterone synthase gene polymorphisms and essential hypertension in blacks and in whites. J Hypertens 21: 87-95, 2003. 